UDC 811'24:378.147:004.77

DOI https://doi.org/10.32841/2409-1154.2021.48-4.3

\author{
Andreiko L. V., \\ $P h D$,
}

Associate Professor at the Foreign Languages Department Education and Research Institute for Business, Economics, and Management of the Sumy State University

Medvedovska D. O., Teaching Assistant at the Foreign Languages Department Education and Research Institute for Business, Economics, and Management of the Sumy State University

\author{
Skarloupina Yu.A., \\ Teaching Assistant at the Foreign Languages Department \\ Education and Research Institute for Business, Economics, and Management \\ of the Sumy State University
}

Turchyna T. V., Teaching Assistant at the Foreign Languages Department Education and Research Institute for Business, Economics, and Management of the Sumy State University

\title{
BENEFITS OF INFORMATION AND COMMUNICATION TECHNOLOGIES (ICT) FOR DEVELOPING LANGUAGE SKILLS
}

Summary. The article below is devoted to the usage of information and communication technologies (ICT) in foreign languages teaching and learning in the $21^{\text {st }}$ century higher education. The expediency and practicality of smart usage of the interactive platforms in the process of mastering foreign language is substantiated in the article and the educational functions which are accomplished through the use of information and communication technologies are considered. The higher education sector has been constantly changing; transformational processes in education include the introduction of various innovations, thus providing a great number of opportunities which, as our practical experience shows, are hard to overestimate. The presence of information and communication technologies in contemporary education allows to create new ways of self-development for both students and teachers, optimizes the organization of the educational process by constantly involving modern digital technologies as a natural part of learning. The potential of ICT, as well as some advantages of ICT, for the development of language skills in the process of mastering a foreign language are identified in the article with the help of examples taken directly from the materials used in 2020-2021 academic year, so that it is possible to consider the impact of distant learning, which became relevant because of quarantine restrictions. The article focuses on the ways ofimplementing blended learning and flipped classroom methods, when ICT are considered to be an integral part of the $21^{\text {st }}$ century teaching and learning. The idea is that ICT should be integrated into the learning process, not sporadically but constantly, in order to make them not just a way to entertain students, but means to break psychological barriers, encourage students' creativity, teamwork and, obviously, to develop language skills: listening, reading, speaking and writing. Moreover, it should be mentioned that, last but not least, using ICT is absolutely necessary nowadays for development students' autonomy, which, in its turn, is a crucial part of life-long learning.

Key words: information and communication technologies, language skills, educational resources, learning process.
Introduction. Integration of information and communication technologies (ICT) with scientific and industrial spheres is a distinctive feature of modern society which requires from all members of the information society to be ready to use ICT in their professional activities. In this regard, one of the priority areas of informatization in modern society is the process of informatization of education, the main direction of which is the introduction of information and communication technologies in the learning process. As one of the ways to modernize secondary and higher education many researchers consider a rational combination of traditional educational technologies and modern ICT. The higher education sector is constantly changing. Today's learning environment is more interactive than ever. Technology and digital tools are transforming teaching methods which improve teaching in colleges, institutes and universities. Moreover, information and communication technologies make interaction possible not only in the classroom but online as well. One of the main reasons why many businesses are still running effectively (education, administration, banks, insurance, etc.) is the use of information and communication (ICT) technologies that facilitate working and studying remotely. Educational institutions are using ICT to create alternative learning ways through digital technologies and online educator resources. Video calls, file sharing, remote access to a learning center, and platforms enable students and teachers of all age groups to cooperate. Information and communication technologies (ICT) make students' common work mutually beneficial. There are a lot of convenient tools which can be used during online learning. Open educational resources are not limited with the usage of such educational platforms as British Council, BBC and Cambridge English. Explaining grammar, introducing new vocabulary or a topic for brainstorming discussion can be also done with the help of such platforms as Flippity, Visia, LyricsTraining, Audacity, Moodle and others. The thing is that ICT 
let users create their own content which is a valuable opportunity for both a teacher and a student.

Analysis of recent research and publications. Undoubtedly, the presence of information and communication technologies is becoming more noticeable in the field of education, as can be seen from numerous publications in recent years in domestic and foreign methodological literature. Globally, this problem is considered in the works of V.Yu. Bykov, R.S. Gurevich, M.M. Kozyara, V.G. Kremenya, N.G. Nichkalo, S.O. Sysoeva, V.A. Travneva, M. Ally, J. Trexler, G. Davis, R. Dimock, M. Burns and others. Since the modern specialist cannot exist without knowledge of a foreign language, its in-depth study has become one of the most important tasks of the training system in the developed countries.

One of the effective ways to solve the above mentioned problem is the integration of creative activities for both teachers and students. Of course, creativity has always been an integral part of the process of teaching foreign languages, but modern conditions, in particular, the rapid development of information and communication technologies provide many new educational opportunities.

The purpose of the article is to substantiate the relevance and determine the benefits of using information and communication technologies in the process of learning foreign languages.

Discussion and results. According to UNESCO (2002) "ICT is a scientific, technological and engineering discipline and management technique used in handling information, its application and association with social, economic and cultural matters".

The introduction of these technologies allows you to more accurately assess the level of language proficiency, get a significant number of additional tasks for self-completion, automate the implementation and verification of homework and improve the learning process and the level of foreign language proficiency in general.

Students who have different levels of language competence have different needs as well as different expectations of a language course, such as getting the basic understanding of grammar rules, having an opportunity to practice speaking, getting ready for an exam, preparing for their future job, etc. This may lead to some kind of misunderstanding and embarrassment if all of them have to study in the same group.
Information and communication technologies (ICT) make students' common work mutually beneficial, for instance by giving access to multi-leveled interactive exercises (learnenglish.britishcouncil.org can be a good example of such a platform). Students of any level can benefit from practicing grammar or vocabulary as many times as they can without getting bored, seeing the results immediately without having to wait for checking, receiving a feedback etc. The platform also provides students with huge amount of authentic materials (video and audio podcasts, reading materials) which make the learning process relevant, efficient and interesting for students.

Even such a usual activity as reading can be transformed and optimized with the help of ICT. Reading, of course, is present in our lesson plans both for classroom (now distant) lessons and as self-study materials. But in fact, we usually pay much more attention to the other kinds of activities, listening or speaking for instance. As a result, some students see texts just as some kind of food for thought, an idea for future discussion, so they do not make much effort to understand every detail of it. Reading can be "updated" by using hyperlinks instead of glosses or just encouraging students to use online dictionaries, e. g. https://dictionary.cambridge.org/, as it can be seen in the following example:

When your job hinges on how well you talk to people, you learn a lot about how to have conversations - and that most of us don't converse very well. Celeste Headlee has worked as a radio host for decades, and she knows the ingredients of a great conversation: Honesty, brevity, clarity and a healthy amount of listening. In this insightful talk, she shares 10 useful rules for having better conversations. "Go out, talk to people, listen to people", she says. "And, most importantly, be prepared to be amazed".

Source: https://www.ted.com/talks/celeste_headlee_10_ways_ to have a better conversation

In this text, which is an introduction to a video exercise, unknown words are introduced in the form of hyperlinks, so students can find the meanings in the dictionary quickly in order to save time for further discussion. In fact, reading of any text can be enriched by using such common methods as Google search or online dictionaries. The next series of exercises followed by the task show how we can make reading activity relevant and meaningful.

THE MOST INSTAGRAMMABLE VILLAGES IN BRITAIN FOR YOUR NEXT STAYCATION
Source: https://metro.co.uk/2020/07/I8/instagrammable-villages-britain-next-staycation-13007792/
Who need a plane ride when so much beauty is on the doorstep? (Picture: Getty Images)




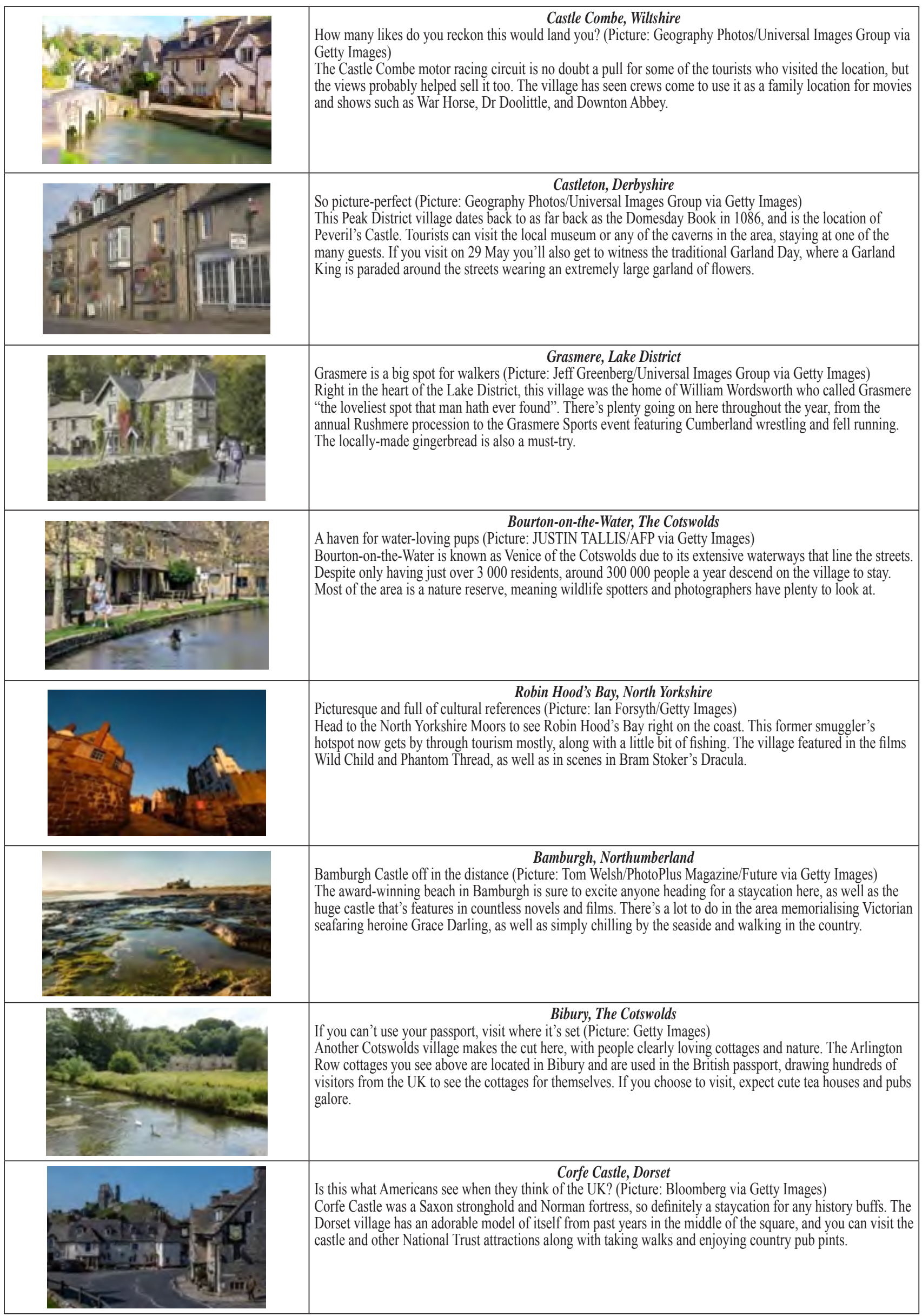




\section{Pre-reading activities}

1. Think about the following questions:

a. Did you have a chance to travel this summer?

b. What was the best place you've visited? Why did you like it?

c. Do you have photos of this place in your smartphone's memory? Did you post them in Instagram?

$d$. Where would you like to go if you have a chance?

e. What do you think a "staycation" is?

2. Match the words with their meanings.

\begin{tabular}{|l|l|}
\hline - destination & - a holiday that you take at home or near your home rather \\
- spot & than travelling to another place \\
- staycation & - a particular place \\
- to feature & - a small addition or detail that makes something better \\
- to take over & - artificially attractive or too perfect \\
- to witness & - the place where someone is going or where something is \\
- touch & being sent or taken \\
- twee & - to show or advertise someone or something as the most \\
& important or most obvious part \\
& - to begin to have control of something \\
& - to see something happen \\
\hline
\end{tabular}

Source: https://dictionary.cambridge.org/

\section{While-reading activities}

Have you heard about these places before? titles)?

Do you see any familiar facts in the article (e. g. books or films

\section{Post-reading activities}

1. Would you like to visit any of these places? Why?

2. Find the adjectives the authors use to describe British beauty spots.

3. Can you think of more adjectives to describe a location? Make a word cloud of them (using wordart.com)

Task

Write a short article about staycation destinations in your country.

You will work together (using Google Document). Each of you is expected to write about 1 destination. You can add a photo to your text.

Firstly (pre-reading activity) students are expected to refresh their background knowledge or expand it (they can use their phones or computers to show some photos, use Google search to find out the meaning of the word "staycation", etc. The vocabulary introduced in the second task is supported with a link to an online dictionary. By the way students have the link to the original authentic article, so they its date and relevance. The while-reading activity is aimed to keeping students interested (actually, hyperlinks to the information about the places mentioned in the article can be provided as well, but this might make the activity too long). The aim of the post-reading activity is, obviously, to practice adjectives, and here ICT can be of great help. Making a word cloud with the help of Wordart is usually an engaging group activity. Finally, the task of creating a "travel guide" reveals the potential of Google Documents for productive team work.

Speaking about students', creating their own content is an issue of great importance, as far as it turns an exercise into a task. By a "task" we mean a clearly formulated, meaningful situation based on some everyday or professional activities when learners need to use their second language competences in order to achieve a certain result. This brings us to the idea that open educational resources are not limited with the usage of educational platforms (British Council, BBC, Cambridge English, etc.). The thing is that ICT let users create their own content which is a valuable opportunity for both a teacher and a student.

Explaining grammar, introducing new vocabulary or a topic for brainstorming discussion can be done with the help of a game platform Flippity (flippity.net) which allows turning a usual Excel sheet into an interactive activity, e.g. https://www.flippity.net/mg.php?k=1B9A PL1QLUrMTs75bZWAsczKzvCKTgRBt7055U8SfSkw.

Any video can be turned into a language learning tool, an interactive exercise, with the help of such platforms as Vizia which allows to insert questions into the video (an example can be found here: https://vizia.co/videos/6538c9a827a2f82932d30f/share).

Moreover, information and communication technologies make interaction possible not only in the classroom but online as well. Of course, video conferences via Zoom, Google Meet or Microsoft Teams are of great help, but it is important for language learners to be able to share their works with the others, either for peer review or just for exchanging ideas, for instance, using padlet "walls" (examples: $\quad \mathrm{https} / / / \mathrm{padlet} . c 0 \mathrm{~m} /$ skarloupina/feml_e_1_20_21, https://padlet.com/skarloupina/1_20_21_ie_01a).

Listening comprehension is one of the most ignored skills in English language teaching. Also, it is a difficult skill that learners must face when learning a foreign language. Many factors may influence the understanding of unfamiliar words such as speed of speech, accent, slang words, etc.

That is why if you want to entertain your students and to practice new vocabulary or pronunciation you would like to use such resource as LyricsTraining (https:/lyricstraining.com/play/ ed-sheeran/perfect/HbW8nMdFKb). LyricsTraining mentions that their site is " $<\ldots>$ an easy and fun method to learn and improve your foreign languages skills through the music videos and lyrics of your favorite songs". This platform turns popular songs into a lesson on spelling, listening, and vocabulary.

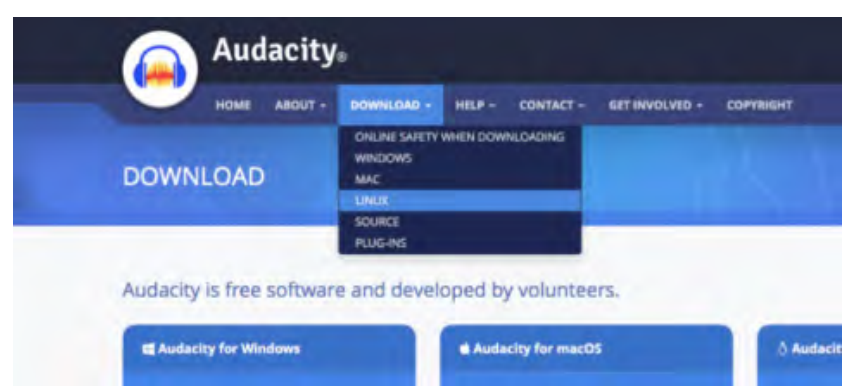

Your students only see the lyrics line by line, as they are sung, and this is the challenge with the second and third options: they have to try to type or select the correct words before the next line starts. If they are fast and don't make many mistakes, students score will be higher. Of course, it's not enough to put a song on for your students. The song which your student's practice should have a language or grammar target allowing the student to discover, identify or reinforce something that you have on your curriculum and in your lesson plan.

Although you should remember to keep in mind your student's likes in music. The wrong song can turn your student off and he'll miss the point of the activity completely. It may be a good decision to give such task as a home task, and then you can organize some sort of competition. 
For training students' listening skills it is also possible to use the Audacity application https://www.audacityteam.org/download/. It is a free program designed to create, edit and export audio files. It can be used to record texts, dictations, transfer them to other programs, to create music videos, add sound effects.

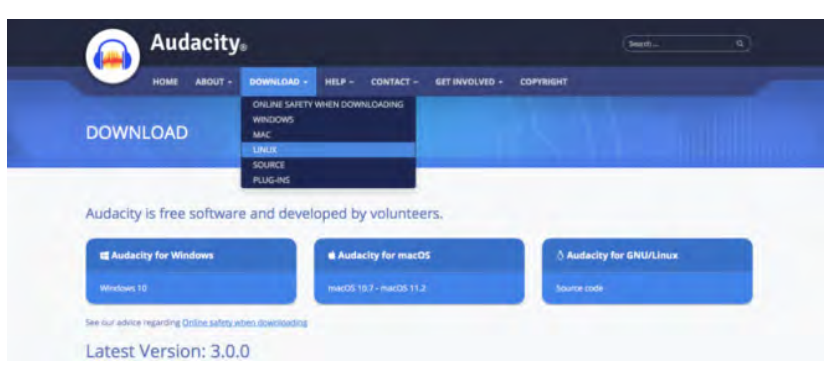

One of the tasks for such workout may be the following. You choose the text which you would like to work with and download it to the application. With the help of Audacity app cut the text into several parts and place them at the any virtual board you work with (Padlet, Jamboard). Then you may ask your students to organize all the parts of the text into the correct order, they can listen several times if it is necessary. Also, you can ask them to name the text, to discuss it, etc.

Another useful tool which can be used during online learning is Moodle. Moodle (Modular Object-Oriented Dynamic Learning Environment) is a modular object-oriented dynamic learning environment, also called a learning management system, course management system, virtual learning environment or simply a learning platform that provides teachers, students and administrators have a large set of tools for computer-based learning, including distance learning [1].

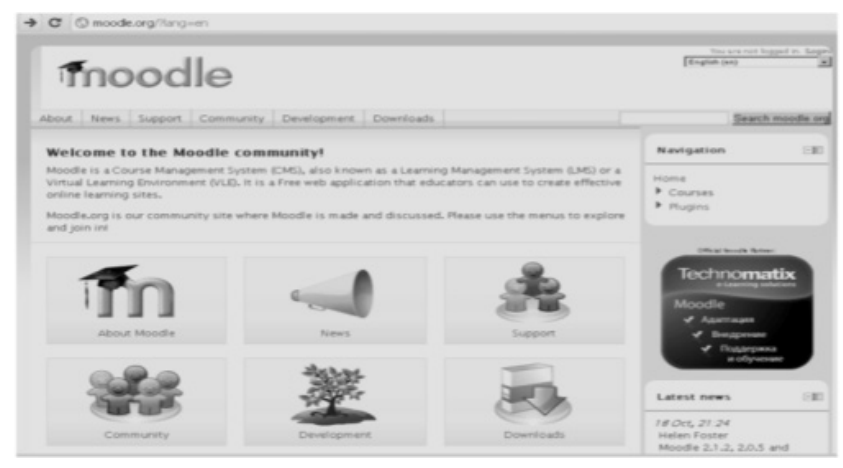

Moodle provides the ability to create and manage its own information and training resources. This is completely flexible system: you can create and manage a distance course yourself, control access to your courses yourself, use time constraints, create your own knowledge assessment systems, control sending students to check tasks, record tasks sent late, allow or to forbid students to retake control tasks (modular or final - tests, exams), etc. Tasks or activities in the Moodle distance learning system are learning objects that provide quick communication between teacher and student, their feedback, and active interaction between students, which in our opinion is one of the most important components of distance learning. Extensive communication capabilities are one of Moodle's advantages. You can use the forum and hold group discussions, rate messages, attach files of any format. During communication in private messages and comments there is an opportunity to discuss a specific problem with the teacher in person. In the chat, the discussion takes place in real time. Moodle provides a wide range of opportunities to use multimedia in the system. The use of video and audio materials, drawings significantly increases the productivity of teaching and students' interest in learning new material. Because these elements of learning involve students working with them, each of the course objectives can be assessed on an arbitrary scale. The teacher can assign the task any number of times, but in this case the type of assessment is determined: the maximum score, the average score of several attempts, the first or last attempt.

Conclusions. Students around the world are free to use technology for everyday communication, creativity and information exchange. Today the first generation of students has grown up for whom mastery of digital instruments is a habit. With the help of these tools students receive information and form their knowledge. Digital tools, many of which are collaborative are available whenever and wherever the Internet is. Students expect education to be similarly authentic, relevant and interactive.

ICT is one of the major factors for producing the rapid changes in our society. It can change the nature of education and roles of students and teacher in teaching learning process. The prospect of further research is to conduct experimental studies of the practical application of different types of ICT in the process of learning English in order to select the most effective of them.

\section{References:}

1. Davies G., (N.D.). CALL (Computer assisted language learning). URL: https://www.llas.ac.uk/resources/gpg/61.

2. $\quad$ Dimock K.V., Burns M., Heath M., Burniske J. Applying technology to restructuring learning: How teachers use computers in technology assisted constructivist learning environments. Austin, TX: SEDL. 2001. URL: https://osvita.ua/vnz/high_school/72285/.

3. Mills D.J. LyricsTraining.com. The Electronic Journal for English as a Second Language. 2010. Vol. 14. P. 2-10. URL: http://www.tesl-ej. org/pdf/ej54/m3.pdf.

4. Rodríguez-Bonces M., Rodríguez-Bonces J. Task-Based Language Learning: Old Approach, New Style. A New Lesson to Learn - Profile: Issues in Teachers' Professional Development. 2010. Vol. 12. № 2. URL: https://revistas.unal.edu.co/index.php/ profile/article/view/17691/36825.

5. UNESCO. Information and Communication Technologies in Teacher Education, A Planning Guide. Paris : UNESCO, 2002. 240 p.

6. Walden University. Educators, technology and 21 st century skills: Dispelling five myths. 2010. URL: www.waldenu.edu/DegreePrograms/Masters/36427.htm.

7. Триус Ю.В., Герасименко І.В., Франчук В.М. Система електронного навчання BH3 на базі MOODLE: методичний посібник. Черкаси, 2012. $220 \mathrm{c}$.

8. Сысоев П.В., Евстигнев М.Н. Создание авторских учебных Интернет-ресурсов по иностранному языку. Интернет-журнал «Эйðoc». 2008. URL: http://www.eidos.ru/journal/2008/0516-4.htm.

Андрейко Л. В., Медведовська Д. О., Скарлупіна Ю. А., Турчина Т. В. Переваги інформаційно-комунікативних технологій (IКТ) для розвитку мовних навичок

Анотація. Статтю присвячено використанню інформаційно-комунікаційних технологій у вивченні іноземних мов у закладах вищої освіти. Обгрунтовується доцільність і практичність їх використання у процесі оволодіння іноземною мовою. Розглядаються навчальні функції, які реалізуються через використання інформаційно-комунікаційних технологій. Присутність інформаційно-комунікаційних 
технологій в освіті дає змогу створювати нові способи навчання для студентів та викладачів, оптимізує організацію навчального процесу шляхом постійного залучення сучасних цифрових технологій як невід'ємного складника навчання. Визначені переваги інформаційно-комунікаційних технологій для розвитку мовних навичок у процесі оволодіння іноземною мовою. Сектор вищої освіти постійно змінюється. Трансформаційні процеси в освіті включають упровадження різноманітних інновацій. Більше того, інформаційно-комунікаційні технології роблять можливою взаємодію не лише в класі, а й в Інтернеті. Однією з головних причин того, чому багато підприємств досі ефективно працюють (освіта, адміністрація, банки, страхування тощо), є використання інформаційно-комунікаційних технологій, які полегшують дистанційну роботу й навчання. Навчальні заклади використовують інформаційно-комунікаційні технології для створення альтернативних способів навчання за допомогою цифрових технологій та інтернет-ресурсів для викладачів. Відеодзвінки, обмін файлами, віддалений доступ до навчального центру та платформ дають змогу співпрацювати студентам і вчителям усіх вікових груп. Інформаційно-комунікаційні технології роблять спільну роботу студентів взаємовигідною. $\mathcal{E}$ безліч зручних інструментів, якими можна скористатися під час онлайн-навчання. Відкриті освітні ресурси не обмежуються використанням таких освітніх платформ, як Британська Рада, ВВС та Cambridge English. Пояснення граматики, введення нової лексики або теми для обговорення мозкових штурмів також можна зробити за допомогою таких платформ, як Flippity, Vizia, LyricsTraining, Audacity, Moodle тощо. Річ у тім, що інформаційно-комунікаційні технології дають змогу користувачам створювати власний контент, що є цінною можливістю як для вчителя, так і для студента.

Ключові слова: інформаційно-комунікативні технології, мовні навички, освітні ресурси, навчальний процес. 